\title{
HUBUNGAN KONSEP DIRI DAN KEPERCAYAAN DIRI DENGAN KEMAMPUAN KOMUNIKASI INTERPERSONAL PADA REMAJA PUTUS SEKOLAH
}

\author{
Rahmah Putri Puspitasari dan Hermien Laksmiwati \\ Program Studi Psikologi Universitas Negeri Surabaya \\ e-mail: hlaksmiwati@yahoo.com
}

\begin{abstract}
The Relation between Self-concept, Self-confidence and Interpersonal Communication Skills among The School Dropouts in Rural Area. This research was correlational study. Subjects of this study were Elementary School, Junior High School and Senior High School dropouts in Keling village, Kediri whose ages ranged from 18-22 years. The number of population of this study were 137 dropouts from which 22 dropouts were recruited as the sample. Data collected using questionnaires and analysed using multiple regression analysis. The result showed that there is no significant correlation between self-concept, self confidence, and interpersonal communication ability among the participants with $r_{x y}=2.944$. The power of the relation between self-concept, self-confidence and interpersonal communication ability was $23.7 \%$ which means that there will be $76.3 \%$ contribution of other variables to influence the interpersonal communication ability which have not been observed in this study.
\end{abstract}

Keywords: Self-concept, self-confidence, interpersonal communication skills, school dropouts.

\begin{abstract}
Abstrak: Penelitian ini merupakan penelitian korelasional. Subjek penelitian adalah remaja putus sekolah tingkat SD, SMP maupun SMA di desa Keling, Kediri yang berusia 18-22 tahun dan belum menikah. Populasi dalam penelitian ini berjumlah 137 remaja putus sekolah dan sampelnya 22 remaja putus sekolah. Teknik pengumpulan data dalam penelitian ini menggunakan angket. Metode analisis data yang digunakan adalah Analisis Regresi Linier Berganda. Hasil penelitian menunjukkan tidak ada hubungan konsep diri dan kemampuan komunikasi interpersonal, kepercayaan diri dan kemampuan interpersonal, serta konsep diri dan kepercayaan diri dengan kemampuan komunikasi interpersonal pada remaja putus sekolah di desa Keling, Kediri dengan $r_{x y}=2,944$. Kekuatan hubungan konsep diri dan kepercayaan diri dengan kemampuan komunikasi interpersonal sebesar $23,7 \%$ yang berarti ada variabel lain yang tidak diamati dalam penelitan ini sebesar $76,3 \%$ yang mempengaruhi kemampuan komunikasi interpersonal.
\end{abstract}

Kata kunci: Konsep diri, kepercayaan diri, kemampuan komunikasi interpersonal, remaja putus sekolah.

Manusia akan mengalami perkembangan dalam kehidupannya, baik bersifat maju maupun sebaliknya. Salah satu perkembangan yang harus dilalui manusia adalah perkembangan pada masa remaja. Masa remaja merupakan periode transisi perkembangan antara masa anak-anak dan masa dewasa yang melibatkan perubahanperubahan biologis, kognitif, dan sosioemosional. Rentang masa remaja dimulai sekitar usia 10 sampai dengan 13 tahun dan berakhir pada sekitar usia 18 sampai dengan 22 tahun (Santrock, 2003: 26).
Masa remaja berada di antara anak-anak dan orang dewasa. Remaja masih belum mampu untuk menguasai fungsi-fungsi fisik dan psikisnya (Monks, 2006: 259). Ditinjau dari segi tersebut mereka masih termasuk golongan anak-anak, mereka masih harus menemukan tempat dalam masyarakat. Pada umumnya mereka masih belajar di sekolah menengah atas atau perguruan tinggi. Bila bekerja, mereka hanya melakukan pekerjaan sambilan dan belum mempunyai pekerjaan tetap. Hal tersebut membuat batas antara masa remaja dan masa dewasa makin lama makin 
kabur karena sebagian remaja yang putus sekolah memutuskan untuk bekerja.

Anak-anak dan remaja menghabiskan waktu bertahun-tahun bersekolah sebagai anggota dari suatu masyarakat kecil dimana terdapat beberapa tugas untuk diselesaikan. Sekolah juga menjadi tempat bagi pengenalan diri dan orang lain serta peraturan yang menjelaskan batasan perilaku, perasaan, dan sikap. Pengalaman yang diperoleh anak-anak dan remaja di masyarakat ini (sekolah) memiliki pengaruh yang besar dalam perkembangan identitasnya, keyakinan terhadap kompetensi diri sendiri, gambaran hidup dan kesempatan meraih cita-cita, hubungan-hubungan sosial, batasan mengenai hal yang benar dan salah, serta pemahaman mengenai bagaimana sistem sosial di luar lingkup keluarga berfungsi (Santrock, 2003: 255).

Setiap remaja memiliki kepribadiannya masing-masing. Kepribadian terbentuk sepanjang hidup kita (Rakhmat, 2005: 13). Selama itu pula komunikasi menjadi penting untuk pertumbuhan pribadi kita. Kita belajar menjadi manusia juga melalui komunikasi. Setelah melalui proses interaksi yang semakin kompleks, barulah terbentuk kepribadian. Komunikasi tidak hanya dalam hal berkomunikasi dengan orang lain, tapi juga termasuk bagaimana seorang individu merespon gerak-gerik tubuh dan nada suara. Memiliki kemampuan komunikasi yang baik tidak terbatas pada dunia kerja tetapi semua bagian penting dalam kehidupan. Dalam dunia kerja, kemampuan komunikasi yang efektif adalah penting karena mereka memainkan peran dalam menentukan kesuksesan seseorang. Komunikasi merupakan kegiatan yang sangat utama dalam proses interaksi. Menurut Mulyana (2005: 73), komunikasi interpersonal adalah komunikasi antara orang-orang secara tatap muka, yang memungkinkan setiap pesertanya menangkap reaksi orang lain secara langsung, baik secara verbal atau nonverbal.

Melalui komunikasi kita menemukan diri kita, mengembangkan konsep diri, dan menetapkan hubungan kita dengan dunia di sekitar kita. Hubungan kita dengan orang lain akan menentukan kualitas hidup kita. Perilaku manusia berpusat pada konsep diri, yaitu persepsi manusia tentang identitas dirinya yang bersifat fleksibel dan berubah-ubah, yang muncul dari suatu medan fenomenal (Rakhmat, 2005: 32). Konsep diri erat kaitannya dengan proses hubungan interpersonal yang vital bagi perkembangan kepribadian. Konsep diri mewarnai komunikasi kita dengan orang lain sekaligus kita menjadi subjek dan objek persepsi (Rakhmat, 2005: 80-99).

Konsep diri merupakan faktor yang sangat menentukan dalam komunikasi interpersonal karena setiap orang bertingkah laku sedapat mungkin sesuai dengan konsep diri (Rakhmat, 2005: 104). Menurut Rogers (Alwisol, 2008: 269), konsep diri adalah konsep menyeluruh yang ajeg dan terorganisir yang tersusun dari persepsi ciri-ciri mengenai "P" atau " $m e$ " (aku sebagai subjek atau aku sebagai objek) dan persepsi hubungan " $I$ " atau " $m e$ " dengan orang lain dan berbagai aspek kehidupan, berikut dengan nilai-nilai yang terlibat pada persepsi tersebut. Konsep diri menggambarkan konsepsi orang mengenai dirinya sendiri, ciri-ciri yang dianggapnya menjadi bagian dari dirinya. Konsep diri juga menggambarkan pandangan diri dalam kaitannya dengan berbagai perannya dalam kehidupan dan dalam kaitannya dengan hubungan interpersonal.

Brooks (dalam Rakhmat, 2005: 105) menyatakan bahwa suksesnya komunikasi interpersonal banyak tergantung pada kualitas konsep diri seseorang, positif maupun negatif. Berkaitan dengan konsep diri positif dan konsep diri negatif, beberapa indikator dari konsep diri positif mengarah pada kepercayaan diri yang tinggi pada individu. Keinginan untuk menutup diri, selain karena konsep diri yang negatif juga timbul dari kurangnya kepercayaan kepada kemampuan sendiri. Orang yang kurang percaya diri akan 
cenderung sedapat mungkin menghindari situasi komunikasi (Rakhmat, 2005: 109). Menurut Santrock (2003: 336), rasa percaya diri adalah dimensi evaluatif yang menyeluruh dari diri. Rasa percaya diri juga disebut sebagai harga diri atau gambaran diri. Sebagai contoh, seorang remaja bisa mengerti bahwa ia tidak hanya seseorang, tetapi ia adalah seseorang yang baik. Meskipun tentu saja tidak semua remaja memiliki gambaran positif yang menyeluruh tentang diri mereka. Kepercayaan diri secara sederhana bisa dikatakan sebagai suatu keyakinan seseorang terhadap segala aspek kelebihan yang dimilikinya dan keyakinan tersebut membuatnya merasa mampu untuk bisa mencapai berbagai tujuan di dalam hidupnya (Setiyo, 2010). Kepercayaan diri mendorong seseorang untuk mencoba bidang-bidang identitas baru, mengambil resiko positif, memajukan diri sendiri, dan mengembangkan kecakapan.

Dari penjelasan di atas dapat disimpulkan bahwa individu yang memiliki konsep diri positif akan bersikap optimis, percaya pada diri sendiri, dan selalu bersikap positif terhadap segala sesuatu, bahkan terhadap kegagalan yang dialami. Kegagalan tidak dipandang sebagai akhir segalanya, namun dijadikan sebagai penemuan dan pelajaran berharga untuk melangkah ke depan. Individu yang memiliki konsep diri positif akan mampu menghargai dirinya sendiri dan melihat hal-hal yang positif yang dapat dilakukan demi keberhasilan di masa yang akan datang. Sebaliknya, individu yang memiliki konsep diri negatif meyakini dan memandang bahwa dirinya lemah, tidak berdaya, tidak dapat berbuat apa-apa, tidak kompeten, gagal, malang, tidak menarik, tidak disukai, dan kehilangan daya tarik terhadap hidup. Individu seperti ini akan cenderung bersikap pesimistis terhadap kehidupan dan kesempatan yang dihadapinya. Ia tidak melihat tantangan sebagai kesempatan, namun lebih sebagai halangan. Individu yang memiliki konsep diri negatif akan mudah menyerah sebelum berperang dan jika ia mengalami kegagalan akan menyalahkan diri sendiri maupun menyalahkan orang lain.

Remaja putus sekolah merupakan salah satu contoh remaja yang beresiko mengalami konsep diri negatif. Ketika seorang remaja harus putus sekolah, secara tidak langsung ia akan menganggap dirinya bernasib buruk atau tidak memiliki kemampuan untuk sukses, maka kepercayaan dirinya bisa menurun yang pada akhirnya akan berusaha menghindari terjadinya komunikasi interpersonal. Ketika individu berusaha menghindari komunikasi interpersonal, kemampuan komunikasi interpersonal pun akan rendah, individu cenderung diam dan tidak mengungkapkan gagasan atau ide yang ada di pikirannya.

Fenomena remaja putus sekolah yang ada di Indonesia dapat dilihat dari pendataan remaja putus sekolah yang dilakukan oleh Pemerintah Kota (Pemkot) bersama Dinas Pendidikan (Dispendik) yang diperoleh data bahwa remaja putus sekolah usia 13-18 tahun atau setara dengan usia SMP dan SMA di Kediri tahun 2006 telah mencapai jumlah 4087 remaja (ITS online, 2006). Sementara itu, sebuah survei yang dilakukan oleh peneliti pada tahun 2011 melalui wawancara langsung dengan perangkat desa di desa Keling, salah satu desa yang ada di wilayah Kabupaten Kediri, diperoleh data warga dengan usia antara 18-56 tahun yang tidak lulus SMA mencapai 937 warga. Resiko tertinggi remaja putus sekolah tidak hanya di kota Kediri saja, tetapi tercatat juga di Magelang sebanyak 768 anak. Remaja putus sekolah di Kabupaten Magelang adalah setingkat pendidikan SMP dan SMA. Pada tahun 2009, jumlah siswa yang putus sekolah di SMP mencapai 520 anak dan di SMA248 anak.

Berdasarkan kondisi di atas, maka muncul pertanyaan apakah ada hubungan antara kemampuan komunikasi interpersonal dengan konsep diri? Apakah ada hubungan antara kemampuan komunikasi interpersonal dengan kepercayaan diri pada remaja putus 
sekolah? Penelitian ini dilakukan untuk menjawab pertanyaan-pertanyaan tersebut. Penelitian ini mengambil hipotesis bahwa ada hubungan antara konsep diri dengan kemampuan komunikasi interpersonal pada remaja putus sekolah dan ada hubungan antara kepercayaan diri yang dimiliki remaja putus sekolah dengan kemampuan komunikasi interpersonalnya.

\section{METODE}

Penilitian ini menggunakan metode kuantitatif berupa studi korelasi untuk melihat hubungan antara tiga variabel, yaitu konsep diri (X1), kepercayaan diri (X2), dan kemampuan komunikasi interpersonal remaja putus sekolah (Y).

\section{Sampel}

Karakteristik populasi dalam penelitian ini adalah remaja laki-laki dan perempuan yang mengalami putus sekolah di tingkat SD, SMP, maupun SMA, berusia 18-22 tahun dan belum menikah. Populasi dalam penelitian ini sebanyak 137 warga di desa Keling, Kediri. Populasi ini dapat diketahui melalui observasi pendahuluan yang dilakukan di desa Keling, Kediri terhadap Kepala Dusun Jegles, desa Keling dan remaja putus sekolah yang berusia 18-22 tahun dan belum menikah. Berdasarkan observasi pendahuluan tersebut diperoleh jumlah remaja putus sekolah sebanyak 137 warga.

Mengingat jumlah sampel yang diperoleh lebih dari 100, maka peneliti menggunakan 22 subjek atau $16,06 \%$ dari jumlah keseluruhan sampel. Hal itu sesuai dengan apa yang dikemukakan Arikunto (2002: 112), bahwa besarnya sampel yang diambil dalam suatu penelitian apabila populasinya kurang dari 100, diharapkan bisa mengambil semua anggota populasi sebagai sampel penelitian, tapi jika jumlah populasinya besar atau lebih dari 100 dapat diambil sampel antara 10\%-25\% atau lebih. Adapun teknik yang dipakai dalam pengambilan sampel ini adalah teknik purposive sampling dengan menentukan karakteristik populasi dalam penelitian ini, kemudian sampelnya diperoleh dari sebagian jumlah populasi yang memenuhi kriteria. Setelah tahap ini dilakukan random sampling, yaitu sebagian jumlah populasi yang memenuhi kriteria diacak hingga ditemukan sampel yang mewakili penelitian.

\section{Teknik Pengumpulan Data}

Alat yang dipakai untuk mengungkap Kemampuan Komunikasi Interpersonal, Konsep Diri dan Kepercayaan Diri adalah dengan menggunakan kuesioner/angket. Angket Kemampuan Komunikasi Interpersonal terdiri dari 21 butir pernyataan, 11 aitem favorabel dan 10 aitem unfavorabel. Angket Konsep Diri terdiri dari 25 butir soal, 16 aitem favorabel dan 9 aitem unfavorabel. Angket Kepercayaan Diri terdiri dari 26 butir soal, 15 aitem favorabel dan 11 aitem unfavorabel. Rentang skor subjek angket Kemampuan Komunikasi Interpersonal bergerak mulai dari 47-63. Angket Konsep Diri bergerak mulai dari 58-83. Angket Kepercayaan Diri bergerak mulai 56-80. Berdasarkan hasil reliabilitas dapat diketahui bahwa angket Kemampuan Komunikasi Interpersonal, Konsep Diri dan Kepercayaan Diri memiliki kestabilan atau keajegan yang tinggi.

\section{Teknik Analisis Data}

Penelitian ini menggunakan Analisis Regresi Linier Berganda untuk menganalisis data yang berhasil dikumpulkan. Analisis Regresi Linier Berganda adalah suatu teknik statistik parametrik yang digunakan untuk menguji pertautan dua buah prediktor $\left(\mathrm{X}_{1}\right.$ dan $\mathrm{X}_{2}$ ) dengan variabel kriteriumnya $(\mathrm{Y})$. Dalam hal ini, X1 adalah konsep diri, X2 adalah 
kepercayaan diri, dan Y adalah kemampuan komunikasi interpersonal remaja putus sekolah.

\section{HASIL DAN PEMBAHASAN}

Hubungan antara variabel konsep diri $\left(X_{1}\right)$ dan kemampuan komunikasi interpersonal $(\mathrm{Y})$ serta kepercayaan diri $\left(\mathrm{X}_{2}\right)$ dan kemampuan komunikasi interpersonal (Y) diuji dengan menggunakan uji-t ( $t$-test). Hasil analisis menunjukkan variabel konsep diri $t=0,886$ dan $p$ value $=0,387$. Hal ini menyatakan bahwa tidak ada hubungan antara konsep diri dengan kemampuan komunikasi interpersonal. Variabel kepercayaan diri $t=1,069$ dan $p$ value $=0,298$ menyatakan bahwa tidak ada hubungan antara kepercayaan diri dengan kemampuan komunikasi interpersonal. Hasil uji Analisis Regresi Linier Berganda menyatakan bahwa koefisien korelasi sebesar 2,944, $p$ value $=0,077$ yang berarti $p$ value $>0,05$ dan $N=22$. Berdasarkan hasil tersebut diketahui tidak adanya hubungan secara bersama-sama yang signifikan antara konsep diri dan kepercayaan diri dengan kemampuan komunikasi interpersonal. Kontribusi atau sumbangan efektif hubungan kemampuan komunikasi interpersonal dengan konsep diri dan kepercayaan diri dalam penelitian ini dapat dilihat melalui nilai $R$ Squered. Berdasarkan skor $R$ Squared diperoleh 0,237 yang artinya konsep diri dan kepercayaan diri memiliki sumbangan efektif sebesar $23,7 \%$ dalam hubungannya dengan kemampuan komunikasi interpersonal, dengan kata lain $76,3 \%$ dipengaruhi oleh faktor lain.

Hasil uji hipotesis pada penelitian ini menunjukkan tidak adanya hubungan antara kemampuan komunikasi interpersonal dengan konsep diri dan hubungan antara kemampuan komunikasi interpersonal dengan kepercayaan diri. Hal itu dapat dilihat pada hasil dari uji-t yang menunjukkan nilai signifikansi variabel konsep diri $p$ value $=$
0,387. Hasil tersebut menyatakan bahwa tidak ada hubungan antara konsep diri dengan kemampuan komunikasi interpersonal. Variabel kepercayaan diri $p$ value $=0,298$. Hal ini menyatakan bahwa tidak ada hubungan antara kepercayaan diri dengan kemampuan komunikasi interpersonal yang berarti bahwa kedua hipotesis ditolak. Hasil uji hipotesis hubungan konsep diri dan kepercayaan diri dengan kemampuan komunikasi interpersonal menunjukkan koefisien korelasi sebesar 2,944 yang menunjukkan tidak ada hubungan, $p$ value $=0,077$ berarti $p$ value $>0,05$. Berdasarkan hasil tersebut menunjukkan tidak adanya hubungan secara bersama-sama yang signifikan antara konsep diri dan kepercayaan diri dengan kemampuan komunikasi interpersonal. Ini menunjukkan bahwa hipotesis ditolak. Kontribusi atau sumbangan efektif hubungan kemampuan komunikasi interpersonal dengan konsep diri dan kepercayaan diri dalam penelitian ini dapat dilihat melalui nilai $R$ Squared. Berdasarkan skor $R$ Squared diperoleh 0,237 yang artinya konsep diri dan kepercayaan diri memiliki sumbangan efektif sebesar $23,7 \%$ dalam hubungannya dengan kemampuan komunikasi interpersonal berarti 76,3\% dipengaruhi oleh faktor lain.

Faktor lain yang memiliki kontribusi lebih besar inilah yang memungkinkan tidak adanya hubungan antara kemampuan komunikasi interpersonal dengan konsep diri, kemampuan komunikasi interpersonal dengan kepercayaan diri, serta konsep diri dan kepercayaan diri secara bersama-sama dengan kemampuan komunikasi interpersonal.

Salah satu faktor lain itu adalah hubungan interpersonal. Hal ini sejalan dengan Arnold P. Goldstein (dalam Rakhmat, 2005: 120) yang mengembangkan metode peningkatan hubungan dalam psikoterapi. Ia merumuskan metode ini dengan tiga prinsip, yaitu makin baik hubungan interpersonal makin terbuka pasien mengungkapkan 
perasaannya, makin cenderung ia meneliti perasaannya secara mendalam beserta penolongnya, dan makin cenderung ia mendengar dengan penuh perhatian dan bertindak atas nasihat yang diberikan penolongnya.

Dari situ dapat dikatakan bahwa makin baik hubungan interpersonal, makin terbuka seseorang untuk mengungkapkan dirinya, makin cermat persepsinya tentang orang lain dan dirinya, maka akan semakin memiliki kemampuan komunikasi. Rakhmat (2005: 125) menambahkan bahwa hubungan interpersonal berlangsung melewati tiga tahap, yaitu pembentukan hubungan, peneguhan hubungan, dan pemutusan hubungan.

Pembentukan Hubungan sering disebut sebagai tahap perkenalan. Perkenalan adalah proses penyampaian informasi. Beberapa peneliti seperti Newcomb, Berger, Zunin, dan Duck (dalam Rakhmat, 2005) telah menemukan hal-hal menarik dari proses atau fase dari perkenalan. Fase pertama adalah fase kontak permulaan yang ditandai oleh usaha kedua belah pihak untuk menangkap informasi dari reaksi kawannya. Masingmasing pihak berusaha menggali secepatnya identitas, sikap, dan nilai pihak yang lain. Bila mereka merasa ada kesamaan, mulailah dilakukan proses mengungkapkan diri. Bila mereka merasa berbeda, mereka akan berusaha menyembunyikan dirinya. Hubungan interpersonal mungkin berakhir. Ketika hubungan interpersonal berakhir, individu akan menghindari terjadinya komunikasi interpersonal. Ini dapat menyebabkan individu memiliki kemampuan yang rendah dalam melakukan komunikasi interpersonal.

Peneguhan Hubungan. Hubungan interpersonal tidaklah bersifat statis, tetapi selalu berubah. Untuk memelihara dan memperteguh hubungan interpersonal, perubahan memerlukan tindakan-tindakan tertentu untuk mengembalikan keseimbangan. Ada empat faktor yang penting dalam memelihara keseimbangan ini, yaitu keakraban, kontrol, respon yang tepat, dan nada emosional yang tepat.

Pemutusan Hubungan. Kita dapat menyimpulkan bahwa jika empat faktor sebelumnya tidak ada, maka hubungan interpersonal akan diakhiri. Kita dapat mengambil analisis R. D. Nye yang menyebutkan lima sumber konflik, yaitu kompetisi, dominasi, kegagalan, provokasi, perbedaan nilai. Kompetisi adalah situasi dimana salah satu pihak berusaha memperoleh sesuatu dengan mengorbankan orang lain. Dominasi, salah satu pihak berusaha mengendalikan pihak lain sehingga orang itu merasakan hak-haknya dilanggar. Kegagalan, masing-masing berusaha menyalahkan yang lain apabila tujuan bersama tidak tercapai. Provokasi, salah satu pihak terus-menerus berbuat sesuatu yang ia ketahui menyinggung perasaan yang lain. Perbedaan nilai, kedua belah pihak tidak sepakat tentang nilai-nilai yang mereka anut.

Dari tiga tahap yang telah dijelaskan di atas terlihat jelas pada remaja putus sekolah yang menjadi subjek penelitian. Pada tahap pertama, mayoritas di antara subjek penelitian merasa berbeda dan berusaha menyembunyikan dirinya. Mulai dari menyembunyikan identitas dan menunjukkan sikap menutup diri. Pada akhirnya mereka menghindari terjadi kegiatan komunikasi interpersonal setiap kali dihadapkan pada situasi yang tidak sesuai. Tahap kedua dan ketiga pun tidak terlampaui sehingga tidak tercipta hubungan interpersonal yang baik.

Pola-pola komunikasi interpersonal mempunyai efek yang berlainan pada hubungan interpersonal. Tidak benar anggapan bahwa makin sering orang melakukan komunikasi interpersonal dengan orang lain makin baik hubungan mereka. Persoalannya bukanlah berapa kali komunikasi dilakukan, tetapi bagaimana komunikasi itu dilakukan.

Lebih jauh, Rakhmat (2005: 129) memberi catatan bahwa terdapat tiga faktor 
dalam komunikasi antarpribadi yang bisa menumbuhkan hubungan interpersonal yang baik, yaitu: sikap percaya, sikap suportif, dan sikap terbuka. Faktor sikap percaya adalah yang paling penting di antara berbagai faktor yang mempengaruhi komunikasi interpersonal. "Bila saya percaya pada Anda, bila perilaku Anda dapat saya duga, bila saya yakin Anda tidak akan menghianati saya atau merugikan saya, maka saya akan lebih banyak membuka diri saya kepada Anda". Hal ini seluruhnya akan membuka saluran komunikasi, memperjelas pengiriman dan penerimaan informasi, serta memperluas peluang komunikan untuk mencapai maksudnya. Remaja putus sekolah yang menjadi subjek penelitian kurang memiliki rasa percaya terhadap sesuatu yang baru dan belum mereka kenal. Ini terlihat pada saat pengisian angket telah berakhir mereka tampak menutup diri dan menjawab seperlunya saja ketika peneliti mencoba melakukan wawancara tidak terstruktur.

Menurut teori ekologi Brofenbrenner (dalam Santrock, 2007: 84), konteks sosial di mana anak tinggal dan orang-orang yang mempengaruhi perkembangan anak dan lingkingan sosial yang terdekat adalah keluarga. Berdasarkan teori ekologi Brofenbrener tersebut dapat disimpulkan bahwa lingkungan keluarga memiliki peranan penting dalam membentuk perkembangan anak. Salah satunya adalah perkembangan bahasa yang erat kaitannya dengan kemampuan komunikasi interpersonal. Keluarga adalah lingkungan pertama yang membentuk perkembangan anak baik fisik, kognitif, norma, agama, dan bahasa. Berbicara mengenai lingkungan keluarga, setiap keluarga tentunya memiliki gaya asuh dan peraturannya masing-masing. Menurut Baumrind, seorang pakar gaya asuh, orang tua tidak boleh terlalu menghukum atau terlalu tidak peduli. Sebaiknya orang tua menyusun aturan bagi anak dan pada saat yang sama bersifat suportif, membimbing, dan mengasuh. Ada empat bentuk gaya pengasuhan menurut Baumrind (Santrock, 2007: 90): authoritarian parenting, authoritative parenting, neglectful parenting, neglectful parenting, dan indulgent parenting.

Dari beberapa gaya pengasuhan anak di atas, gaya asuh yang dapat mempengaruhi kemampuan komunikasi adalah authoritarian parenting. Mayoritas para orang tua remaja putus sekolah yang menjadi subjek penelitian menerapkan gaya asuh authoritarian parenting. Mereka memaksakan anak-anak mereka untuk bekerja dan meninggalkan sekolah ketika dianggap sudah layak memiliki pekerjaan. Pendidikan dinilai tidak penting dalam memperbaiki keadaan ekonomi keluarga. Gaya asuh yang seperti ini membuat anak memiliki kesempatan terbatas untuk mengembangkan kemampuannya dalam berkomunikasi dengan orang lain. Hubungan interpersonal yang mereka miliki pun tergolong buruk. Para remaja putus sekolah tersebut cenderung cemas menghadapi situasi sosial, tidak bisa membuat inisiatif untuk beraktivitas, dan keahlian komunikasinya buruk.

Selain gaya asuh anak, budaya atau kultur juga dapat mempengaruhi kemampuan komunikasi interpersonal seseorang. Budaya yang dipertahankan oleh orang tua remaja putus sekolah di desa Keling adalah bekerja sebagai petani dan peternak. Mereka memaksakan anak mereka untuk melanjutkan bekerja sebagai petani atau peternak daripada memperoleh pekerjaan di luar lingkungan desa dan melanjutkan pendidikan. Ini mengakibatkan para remaja merasa dibatasi interaksi sosial dan aktualisasi dirinya. Padahal kemampuan komunikasi interpersonal seseorang hanya dapat berkembang melalui interaksi sosial.

Kemungkinan lain yang dapat menyebabkan hipotesis pada penelitian ini ditolak adalah jumlah sampel yang sedikit dan mendekati $10 \%$ dari jumlah populasi yakni sebesar 16,06\% atau 22 sampel. Signifikansi hubungan pada setiap variabel penelitian mungkin akan bisa dilihat jika dilakukan 
penambahan subjek penelitian. Selain karena jumlah sampel, situasi penyebaran alat ukur dan saat pengumpulan data penelitian juga memungkinkan hipotesis pada penelitian ini ditolak. Penyebaran angket dilakukan pada malam hari dan bersamaan dengan diadakannya hajatan. Ini mengakibatkan sampel penelitian hanya diambil sebesar 22 subjek. Pertimbangannya, 22 subjek penelitian ini yang sudah pasti dapat hadir untuk mengisi angket sebagai alat ukur penelitian.

\section{SIMPULAN}

Penelitian ini menyimpulkan bahwa tidak terdapat hubungan yang signifikan antara konsep diri dan kemampuan komunikasi interpersonal dengan kemampuan komunikasi interpersonal pada remaja putus sekolah. Konsep diri dalam penelitian ini tidak memiliki hubungan dengan kemampuan komunikasi interpersonal. Kepercayaan diri juga tidak memiliki hubungan dengan kemampuan komunikasi interpersonal. Serta konsep diri dan kepercayaan diri secara bersama-sama tidak memiliki hubungan dengan kemampuan komunikasi interpersonal pada remaja putus sekolah di desa Keling, Kediri. Hal ini kurang sesuai dengan teori Brooks (Jalaluddin, 2005: 105) yang menyatakan suksesnya komunikasi interpersonal banyak tergantung pada kualitas konsep diri seseorang, positif atau negatif, karena setiap orang bertingkah laku sedapat mungkin sesuai dengan konsep dirinya. Hal ini juga kurang sesuai dengan pendapat Jalaluddin Rahmat (2005: 108) tentang hubungan antara kemampuan komunikasi interpersonal dengan kepercayaan diri yang menyatakan bahwa keinginan untuk menutup diri, selain karena konsep diri yang negatif timbul dari kurangnya kepercayaan kepada kemampuan sendiri. Orang yang tidak menyenangi dirinya merasa bahwa dirinya tidak akan mampu mengatasi persoalan. Orang yang kurang percaya diri akan cenderung sedapat mungkin menghindari situasi komunikasi. Ia takut orang lain akan mengejeknya atau menyalahkannya.

\section{SARAN}

Saran yang berkaitan dengan hasil penelitian ini bagi peneliti yang mengkaji tema yang sama hendaknya lebih memperhatikan variabel-variabel lain selain konsep diri dan kepercayaan diri yang dapat mempengaruhi kemampuan komunikasi interpersonal pada remaja putus sekolah. Variabel yang memiliki kontribusi lebih besar dalam mempengaruhi kemampuan komunikasi interpersonal pada remaja putus sekolah adalah persepsi interpersonal, atraksi interpersonal, rasa percaya, sikap suportif, sikap terbuka, lingkungan mikro, pola asuh, dan budaya atau kultur. Sebaiknya juga memperhatikan jumlah sampel yang dijadikan subjek penelitian. Memperbanyak sampel memungkinkan dapat mempengaruhi signifikansi hubungan konsep diri dengan kemampuan komunikasi interpersonal, kepercayaan diri dengan kemampuan komunikasi interpersonal, dan hubungan secara bersama-sama konsep diri dan kepercayaan diri dengan kemampuan komunikasi interpersonal. 


\section{DAFTAR PUSTAKA}

Alwisol. (2008). Psikologi Kepribadian. Malang: UMM Press.

Arikunto, S. (2006). Prosedur Penelitian (Susunan Pendekatan Praktek). Yogyakarta: Rineka Cipta.

ITS Online. (2006). Remaja Putus Sekolah (online). Http://digilib.its.ac.id/ITSMaster-3100009035316/6507. Diakses pada 22 Februari 2011.

Monks. (2006). Psikologi Perkembangan. Yogyakarta: Gadjah Mada University Press.

Mulyana, Deddy. (2005). Ilmu Komunikasi Suatu Pengantar. Bandung: Remaja Rosdakarya.

Rakhmat, Jalaluddin. (2005). Psikologi Komunikasi. Bandung: PT. Remaja Rosdakarya.
Santrock, J. W. (2003). Adolescence (Perkembangan Remaja). Jakarta: Erlangga. . (2007). Psikologi Pendidikan. Jakarta: Erlangga.

Setiyo. (2010). Pengaruh Pelatihan Kepercayaan Diri Menggunakan Metode Hipnosis Terhadap Kepercayaan Diri Siswa Kelas X Menghadapi Ujian Semester (2) $\left(\begin{array}{llllll}o & n & l & i & n & e\end{array}\right)$. http://setiyo.blogspot.com/2010/04/peng a ruh-pelatihan-kepercay a andiri_22.html. Diakses pada 10 Februari $201 \overline{1}$. 